University of Wollongong

Research Online

Faculty of Business - Papers (Archive)

Faculty of Business and Law

$1-1-2016$

Industrial relations changes in the Maldives: Critical events and actors

Ali Najeeb

Villa College, Maldives, najeeb@villacollege.edu.mv

Mary Barrett

University of Wollongong, mbarrett@uow.edu.au

Follow this and additional works at: https://ro.uow.edu.au/buspapers

Part of the Business Commons

Research Online is the open access institutional repository for the University of Wollongong. For further information contact the UOW Library: research-pubs@uow.edu.au 


\title{
Industrial relations changes in the Maldives: Critical events and actors
}

\author{
Abstract \\ This paper analyses recent changes in the industrial relations (IR) system in the Maldives. Critical \\ incidents were compiled from interview and document data and analysed using a quasi-grounded theory \\ approach. The analysis shows that, precipitated by the political events of September 2003, profound \\ democratic and IR changes took place, including the emergence of new IR actors and institutions. \\ However, the outcomes of these profound changes were short-lived, reverting to old undemocratic \\ practices and arrangements. The paper highlights the reasons why democratic change occurred as it did \\ in the Maldives and why it reversed.

\section{Keywords} \\ actors, events, critical, industrial, maldives, relations, changes \\ Disciplines \\ Business

\section{Publication Details} \\ Najeeb, A., Barrett, M. (2016). Industrial relations changes in the Maldives: Critical events and actors. \\ Industrial Relations Journal, 47 (2), 181-200.
}




\title{
Industrial relations changes in the Maldives: Critical events and actors
}

\author{
Ali Najeeb, Villa College, Maldives \\ Mary Barrett, School of Management, Operations and Marketing, University of \\ Wollongong
}

\begin{abstract}
This paper analyses recent changes in the industrial relations (IR) system in the Maldives. Critical incidents were compiled from interview and document data and analysed using a quasi-grounded theory approach. The analysis shows that, precipitated by the political events of September 2003, profound democratic and IR changes took place, including the emergence of new IR actors and institutions. However, the outcomes of these profound changes were short-lived, reverting to old undemocratic practices and arrangements. The paper highlights the reasons why democratic change occurred as it did in the Maldives and why it reversed.
\end{abstract}

\section{Introduction}

The institutional perspective has shown how entities arise, acquire identities and interests, and become actors in institutional contexts (Wood et al., 2014). Nevertheless, some aspects of the institutional perspective and, within it, industrial relations (IR) are still developing. For example, although institutional research emphasizes how actors engage in institutional change, understanding of how those actors emerge is still developing (Hwang \& Colyvas, 2011). Further, until recently IR research has largely focused on advanced industrialised nations rather than emerging economies (Kuruvilla and Erickson, 2002; Wood et al., 2014). Moreover, research typically links IR outcomes to countries' economic policies rather than to their path of political development (Thelen, 2009). Addressing these gaps, this paper examines the link between political change and IR developments in the Maldives, considering the following questions: (1) what is the nature and cause of political and IR changes in the Maldives; (2) how did political and IR changes occur; and (3) why did the changes occur as they did? To answer these questions, this paper employs an historical institutional perspective to explore the role of actors in IR events (Thelen, 1999).

The paper covers IR issues in a relatively under-researched context, the Maldives. The study makes three contributions. First, it systematically uses an historical institutional perspective and the literature on the Maldivian political economy to show how institutional and IR change in the Maldives occurred, how new IR actors and institutions were established through political modernization, and how IR gains made as result of political changes backtracked with the reversal of democracy. It also provides a nuanced understanding of the fragility of democratic changes, and provides a more rigorous explanation of the extent to which they caused the February 2012 coup. Second, the study highlights the role of local and international actors at various stages of the Maldivian democratic journey. Third, by using a quasi-grounded theory approach to define and evaluate critical change incidents, the study provides a practical solution to the problem of defining a time-span in which significant institutional change can be seen to have taken place. 
The paper is organized as follows. It first reviews the political and economic development of the Maldives and discusses the role of institutional analysis in IR research. Then, after outlining the study's research method, it analyses political and IR change in the Maldives since 2003, showing how specific actors influenced and/or emerged from the changes. The final section discusses theoretical implications of the findings and suggests future research directions.

\section{The political and economic development of the Maldives}

The Republic of Maldives consists of about 1190 tiny, low-lying coral islands stretched across the equator in the Indian Ocean, with an entire territorial size of 859,000 square kilometres. Only 192 islands are inhabited of which 101 have been developed as self-contained tourist resorts (MTAC, 2015). The population of 310,000 belong to a common race, Maldivian; embrace the same culture and religion, Islam; and speak a common language, Dhivehi (DNP, 2012).

From the 1880s to the mid-1960s, the Maldives was governed by monarchies (Rasheed, 2014). The political state during this period was controlled by the monarchical rulers, their families and elites. The monarchical rule was characterised by the political desires and personal interests of the ruling class. The Maldives was a British protectorate until 1965. However, as the British engagement with the Maldives was intended to ensure political security for the Maldives rather than as a means to develop a mechanism of democratic governance, the Maldives did not inherit a political or legal system from the superior British institutional systems (Rasheed, 2014). As a result, the Maldivian legal system is a complex mixture of Shariah law and English civil and common law (MoFA, 2010).

The Maldives became a republic in 1953 but the First Republic lasted only eight months before reverting to a Sultanate. The Second Republic was established in 1968. Until 2008, the President was elected by the Parliament and endorsed by the public in a referendum. Between 1968 and 2008 Maldivians experienced two presidencies. As the Maldives was under monarchical rule, fundamental rights such as freedom of association and freedom of speech were suppressed under both presidencies (BHRC, 2012). In addition, income and wealth distribution gaps widened, nepotism and corruption were rife (Amnesty International, 2005; US Department of State, 2009), and there was no separation of powers. An embryonic opposition movement emerged in the 1990s, but its voice and discussion of individual rights generally were silenced by government control of the media (Shaheed and Upton, 2008). A personalised political system was created which acted as a barrier for the government to establish democratic governance during the 1990s (Rasheed, 2014). A democratization process began in the early 2000s, leading to the enactment of a new Constitution and the first multi-party election in 2008. Parliamentary and local council elections followed in 2009 and 2010 respectively (MoFA, 2010).

Although free market principles inherited from the period when the Maldives was a British protectorate (Rasheed, 2014) and British trade dominated the region, trade and economic activity did not develop until the 1970s. The Bora merchants who dominated trade in the Maldives until 1960s also functioned in a weak institutional and business environment (Rasheed, 2014). As a result, formal employment is a recent phenomenon in the Maldives. Until the early 1960s, economic activity was paid in kind (HCRM, 2009), but this changed after two major tourist resorts were developed (Najeeb, 2013), which spawned other industries including fishing and construction. 
However family members and associates of the president controlled these economically important sectors, exacerbating precarious forms of employment and the imbalance of wealth and power between capital and labour (ICNC, 2012). While the Maldives today is a democracy with an open, private sector-led economy, disparities in wealth and opportunity remain, especially between the capital and outlying islands. Despite rapid economic growth from tourism, job creation has not matched growth in the working age population (currently about 200,000). In September 2011 there were close to 100,000 expatriate employees in the Maldives mostly in tourism and construction (Naish, 2012) and approximately 44,000 illegal workers (Latheef, 2011). Unemployment among Maldivians in 2012 was 28\% (DNP, 2012).

\section{Institutional analysis in IR research}

Institutional analysis in IR has traditionally focused on formal regulatory institutions such as unions, laws and regulations (Jackson \& Muellenborn, 2012). However, according to Wood and Lane (2012) and Morgan and Hauptmeier (2014), the institutional literature now recognizes that institutions are not as clearly coupled as often depicted, and that with national contexts it is likely that not one but several dominant work and employment relations paradigms are likely to be encountered. Wood et al. (2014) suggest that national institutional arrangements are constantly developing in a non-linear manner, and can never be made to assume the precise form or function as at the time of their original design. This reflects the choices of social actors who, in enacting and contesting specific frameworks, seek to bend structures to suit specific needs, and, in interpreting rules and procedures, invariably impart an element of subjectivity (Wilkinson \& Wood, 2012). The behaviour of these social actors is shaped by 'institutional logics', which provide the 'formal and informal rules of action, interaction, and interpretation that guide and constrain decision makers' (Thornton \& Ocasio, 1999:904). In complex environments, competing or contradictory institutional logics co-exist, creating ambiguity and hence opportunities for actors to initiate change (Najeeb, 2013b). The change process may replace or combine earlier logics resulting in hybrid ideas (Rupidara and McGraw, 2010: 616). Thus institutional change concerns the erosion of an institutional logic which may change or ultimately even disappear (Oliver, 1992).

Researchers following historical institutional analytical perspective place institutions and power relations at the centre of any analysis of change (Thelen, 2009). Historical institutionalism links the emergence of and changes in institutions and employment practices with wider developments in society and the nation-state. Institution building and consolidation result from formative events or crises with the result that 'the longer the institutional arrangements remain in place, the more likely they are to be overturned' (Wilkinson \& Wood, 2012:378). An exogenous event is required for a radical change to be initiated (Wood \& Lane, 2012).

Bronstein (1995:163) argues that as all IR systems bear the marks of their origins, any change to individual, historical, political, legal, economic, ideological, social and cultural variables will change how IR are conducted. Accordingly, studies of IR change have focused on these variables. Kuruvilla and Erickson (2002:173) argue that "at any given moment some forces will be more urgent than others" and, in particular, that external constraints on national institutions such as pressure from transnational institutions predominate in driving actors to engage in institutional change. 
IR scholars have also tried to analyse IR change in terms of whether it reflects evolutionary or discontinuous change (punctuated equilibrium) (Bronstein, 1995; Erickson and Kuruvilla, 1998; Wood et al., 2014). Evolutionary change is characterized by incremental changes which accumulate over a long period (North, 1990). Punctuated equilibrium, in contrast, consists of sharp shifts from one institutional arrangement to another (Streek, 2012). These patterns are revolutionary because a prolonged period of equilibrium or evolution is interrupted by a crisis that throws things into turmoil until a radical new set of institutional arrangements is established. There are three main components of the punctuated equilibrium view of change: deep structure, equilibrium periods, and revolutionary periods (Gersick, 1991). Transformational change to an IR system occurs when there are changes to the components of IR deep structure, that is, to definitions of property rights, the relative status of employees and employers, levels of individualism vs. collectivism, the nature of exchange in the labour market, and to the fundamental strategies of employers, unions, and governments.

Historical institutionalism not only explains change but also explains persistence, stability, continuity and resilience. Institutional path dependency explains why institutions continue to operate in their own particular way (North, 1990). It recognizes that some institutions are deeply embedded, which makes any radical departure from established patterns of behaviour difficult. Stakeholders invest so much in operating within the boundaries created by their institutions that they do not want to follow any alternative pathway. For example, when institutions are inherently undemocratic, they create undemocratic paths for present and future politics (Bell, 2011). As mentioned before, although such pre-existing weak institutional paths may change over time (Thelen, 2009), the nature of such changes depends on the political interactions within the existing institutional setting (Rasheed, 2014). This suggests that any traditionally transmitted undemocratic political practices embedded in the political system may weaken the government's ability to establish progressive IR systems.

\section{Research approach: Data collection and analysis}

The research approach was primarily qualitative, using document searches and face-to-face interviews. Thirty people directly involved in the events and practices being analysed were chosen primarily through purposive and snowball sampling. The interviews used an open-ended format with interviewees being invited to describe their experiences of recent economic, legal and political changes in the Maldives. Interviews were conducted either in English or Dhivehi and lasted between 20 and 75 minutes. Table 1 below indicates the number of participants from specific groups, and the coding system by which the paper refers to each participant.

\section{Table 1 here.}

The data were analysed using a quasi-grounded approach (Glaser \& Strauss, 1967; Corbin and Strauss, 2008) to identify "critical incidents (CIs)". In Flanagan's original (1954) description, a $\mathrm{CI}$ is defined as any human activity sufficiently complete in itself to permit inferences and predictions about the person performing it. This approach, however, is less suited to the historical institutionalist paradigm used here, which seeks understanding of the long-term significance of events and institutions rather than individuals. As Campbell (2004) explains, a particular time-span of critical events can provide an appropriate timeframe for institutional 
analysis, but significant events are difficult to define. An apparently critical event such as the passing of a new law may have little long-term effect whereas an apparently small event may have major consequences.

We did two things to overcome this problem. First, relying on Boselie's (2009:97) definition of a $\mathrm{CI}$ as "a definite and discrete occurrence that interrupts normal procedures or precipitates a crisis", we used a semi-structured rather than an unstructured interview format. Second, interviewer knowledge based on the document analysis and previous interviews was introduced to prompt further reflection. The second adaptation was derived from the quasi-grounded theory approach used in the study. Documentary sources were first searched for key issues which appeared critical in Boselie's (2009) sense, that is, which a substantial number of participants or documentary sources indicated had precipitated a crisis or, alternatively, marked the restitution of equilibrium. They were coded accordingly. Events coded as marking the onset of a crisis or the restitution of equilibrium yielded our timeframe: 2003-2009. These 'crisis onset' and 'crisis ending' events were grouped with events occurring between the two which, again, participants saw as producing a trajectory from crisis onset to crisis ending. This process generated a list of events that could be plausibly shown to encompass all (and only) truly critical incidents. There were 11 such critical incidents (see Table 2).

Table 2 here.

\section{Findings}

The 11 CIs were tentatively grouped into similar thematic categories according to the issues they appeared to embody. The categories were then tested by first comparing CIs as they were reported in the interviews and documentary sources, and then by comparing them with relevant literature (Glaser \& Strauss, 1967; Corbin and Strauss, 2008). This process yielded nine thematic categories: the democratization process, democratization and labour rights, the development of dispute resolution mechanisms, employment legislation and regulation, constitutional changes, employee associations, employer associations, the role of government in IR, and international actors. In the remainder of this section, we outline interviewee perceptions of each theme as it emerged in the CIs and discuss it in terms of the literature on institutional and IR change.

The democratization process: From stringent control to democratic concessions On 19 September 2003 security guards tortured to death an inmate of the Maafushi Prison located in the capital of the Maldives, Male'. Despite government efforts to cover up the matter, the death became public knowledge through the inmate's mother. When the news reached other inmates they rioted. Security guards opened fire on them, killing three and seriously wounding 17 others (BHRC, 2012). Although some condoned the security guards' actions, people took to the streets and began demanding institutional accountability and democratic freedoms. According to a former Secretary-General of the HRCM, the severity of the event provided a focus for the domestic opposition and the international community, enabling them to work together:

They [the opposition] suddenly found an event [which was] sort of drastic [...] which was totally unexpected, which garnered support in both the domestic and the international arena. So it helped consolidate the efforts of the domestic opposition which was backed by the international community. (HR28) 
Several opposition figures gave interviews to the international media exposing the government's human rights violations before going into exile in Sri Lanka. There they established the Maldivian Democratic Party (MDP) and sought international support. Under pressure from within and abroad, in 2004 the government announced a "roadmap to reform" and convened the Constitutional Assembly to amend the Constitution (Maldives Partnership Forum, 2006). A presidential decree in 2005 gave political parties the right to operate in the Maldives (The President's Office, 2007). The MDP, which had been operating in the UK and Sri Lanka, was the first to register. Four parties were registered by the end of 2005 (FIDH, 2012). Pressure from transnational groups resulted in the government undertaking a dialogue - "Westminster talks 2006" - with the opposition. Eight political parties participated in the elections held in 2008.

The reaction of the domestic community to the Maafushi Prison death supports Kristensen and Morgan's (2012) argument that political upheavals allow individual actors to work collectively to reformulate interests and roles. The ensuing events which culminated in the 2008 elections suggest the initial event was sufficiently critical to alter institutional path trajectories (Thelen, 2009). The establishment of the MDP is an example of "purposeful and continual actions of individuals and collective actors", a condition crucial for institutional change (Reay et al., 2006:993). A sociological model of how actors pursue their goals suggests they "pursue legitimacy or taken-for-granted cognitive scripts" (Jackson \& Muellenborn, 2012:475). The government's "road-map to reform" comprised eight key elements including "promoting and strengthening human rights", "enhancing the independence of the judiciary", "a more independent media", and "modernization of the electoral system." These elements along with the Westminster talks in 2006, which will be discussed later, resonate with the scripts associated with a pursuit of democratic legitimacy. Overall, the events triggered by the September 2003 death support the idea that institutions are political outcomes formed through conflicts and compromises between actors, and that if conditions change then actors seek to change institutions (Kristensen \& Morgan, 2012).

Democratization and labour rights - Employment issues flow from the political agenda Following the September 2003 events, employment issues emerged as a common theme in activists' demands. For instance, following the president's call for public debate on constitutional reform, reformists organized a series of forums (minivan bahus) to discuss political and human rights issues. Six forums were held before key leaders were jailed following demonstrations in August 2004 (Shafeeg, 2011). The HRCM also organized public forums in which a recurring demand was for an independent civil service. The demand arose from the fear on the part of politically active government employees that they would be dismissed. As a labour activist recalled:

We wanted the assurance that we would not lose our jobs because we belonged to the opposition. In one of the forums, I even first asked the chair whether I could speak because I was a government employee. (LA22)

Besides these forums, protests were organized by the MDP in association with various workers movements. For example, the MDP and port workers (majooreen) led the 2006 May Day rally. Employment issues were also prominent in these protests. The HR manager of a local resort recalled the scene as follows: 
I saw people holding large banners with slogans such as 'enact employment and pension laws', 'join the ILO', 'allow unions', 'set minimum wage', 'follow international labour standards', 'abolish discrimination', 'equal pay for work of equal value' and so on. (RM16)

The media, which had become relatively free as a by-product of political change, played a key role in advocating employment rights. The opposition movement started a radio station [Minivan radio] which broadcast from the UK. At the same time, the local print media began focusing on employment rights issues. As another labour activist commented:

We started seeing articles in newspapers about labour issues for the first time in 20042005. We saw bold headings such as 'labour rights must be protected by law'. It was unprecedented. We hadn't seen such a thing before, despite the print media such as Haveeru Daily being there since 1979. (LA23)

Through forums, protests, and news media, employees became aware of previously obscure entitlements. For instance, employees became aware that under the blue (1997) Constitution they were entitled to a pension. As a MTAC official noted:

The right to have the pension was even guaranteed in our 'blue Constitution'. But nobody spoke of this before. The opposition blamed the government for not taking action to provide a constitutional right and started to speak about this. (GO25)

In a similar way, employers and employees became aware of a 1994 employment regulation governing employment relations in the private and public sectors, and they started enquiring about it. As a former director of the Labour Relations Authority (LRA) explained:

I was at that time working in the legal department of the employment ministry and we received calls from people - both managers and ordinary employees - enquiring about the labour regulation. They requested to put it up on the website, asked whether the ministry could provide an English version of it and so on. (GO24)

Increased awareness of employment rights led to employees pushing for them both collectively through petitions and strikes, and individually. An example of individual action was a case filed by a government employee who had been dismissed for political reasons. Although such dismissals had been common, no-one had previously challenged them administratively or legally. The judgement favoured the employee. A former director of LRA commented about the government's reaction to this landmark decision:

The government took the matter very seriously and responded swiftly. They wanted to challenge the decision in the High Court. We advised not to do so. But the government still tried to figure out how to avoid such a decision in the future. (GO24)

Bronstein (1995) and Anner (2008), examining IR changes in Latin America between the late 1970s and the mid-1990s, found that the democratization process with its increased freedom of assembly and expression brought hope that employment rights would eventually be granted. Rupidara and McGraw (2010) made a similar finding for Indonesia. These events in the Maldives illustrate how, as in these countries, political dynamics prompted IR developments, and changes to institutional mechanisms encouraged actors to alter institutions (Barley and Tolbert, 
1997). They also indicate the media's role in disseminating and legitimating ideas (Braam et al., 2007) and increasing pressure on institutions (Daniels et al., 2002).

Employment dispute resolution mechanisms - from handmaidens of government to guardians of employment rights As in Latin America, strikes in the Maldives began with political change. The first strike was organized by employees in an international five-star resort (Robinson, 2010). Workers demanded improvements in working conditions and an end to long-standing employment practices favouring expatriates over local workers. Many strikes by resort workers in the period 2005-2008 ended with key employees being sacked (HRCM, 2009). Nevertheless, improvements in line with workers' demands often followed later. As a resort worker said:

We went on strike because we wanted things to be improved for us and to eliminate all sorts of discrimination. We demanded better food and better facilities. The management didn't agree with us. But later on, a local chef was employed and we were given gym facilities. (RW10)

Seeking legitimacy in the eyes of potential foreign investors (Jackson \& Muellenborn, 2012), the government responded quickly and severely to put down the strikes. The introduction of Employment Dispute Resolution Regulation (2011) further limited the constitutional right to strike by imposing numerous conditions on its legality. Similarly, the Employment Tribunal's function was ostensibly to resolve employment disputes, but the Act which established it did not mention stoppages or strikes. Similarly, the 2013 Peaceful Assembly Act restricted demonstrations to locations designated by the government, so that it served as a means of political control rather than to enable peaceful assembly (Najeeb, 2014). These actions show how a powerful actor such as the state can establish and support parallel logics in the regulatory environment

Nevertheless, such conflicting institutional frameworks create loopholes which actors can exploit later and this happened in the Maldives. For example, in response to domestic and international pressure over the events of September 2003, the first human rights commission was established in 2003 by presidential decree (Shafeeg, 2011). However, as its members were handpicked by the president, political and human rights activists pushed for an independent body. As a labour activist noted:

We demanded individual rights to be recognized as equally with state's rights and called for an independent human rights oversight body. (LA22)

In response in 2006 the government passed the Human Rights Act and established an independent Human Rights Commission (US Department of State, 2009). A former SecretaryGeneral of the commission recalled his involvement in some of the HRC's activities as follows:

We conducted a number of rapid assessments and investigations into the abuse of workers and also visited places where migrants were working. We observed a number of abhorrent things [...]. We had a number of meetings with the LRA and published reports and made direct recommendations to these state agencies. (HR28)

Despite the formation of the Employment Tribunal and the LRA, employment-related cases still comprise the vast majority of cases dealt with by the HRCM, with 99 employment related complaints dealt with in 2014 (HRCM, 2015). This finding supports the finding by Heery and 
Frege (2006) that actors who perform IR functions in the absence of traditional IR actors often continue in this role even after more prominent IR actors and systems are established.

Employment legislation and regulations - from fragmentation to protective unity Since the 1960s, the government had used various procedural regulations to administer the employment of government employees (HRCM, 2009). These fragmented regulations were consolidated into a single regulation only in 1994. The new regulation, which extended to both private and public sector employees, covered minimum standards in employment agreements, hiring and firing, promotion, compensation and benefits, working hours, and leave entitlements (The President's Office, 2007) However it lacked critical provisions on discrimination and unfair dismissal (HRCM, 2009). Moreover, few stakeholders were aware of its existence as information about it was not available in the public domain and not disseminated to private sector stakeholders. Accordingly, as a resort manager (RM19) pointed out, “... this regulation was not implemented in the private sector."

An independent civil service was established via the Civil Service Act (2007) as part of the president's "road map to reform". It comprehensively covers the governance of civil service employment. In May 2008, as the democratization movement began, the Maldivian Parliament passed the Employment Act 2008, the first general law governing employment relations. Its objectives were: (1) to protect vulnerable workers' employment rights; (2) to regulate and improve the welfare of both local and expatriate workers; and (3) to pave the way for the Maldives to join the ILO and ratify its core conventions (Employment Act, 2008). It imposed severe penalties for violations of its provisions on forced labour, unfair workplace discrimination, and the employment of minors. It also regulated a range of individual employment matters, the employment of foreign workers, and employment agency activities. Finally, it provided for the establishment of an Employment Tribunal to adjudicate employment disputes. The Tribunal became fully functional in April 2009. The Act also authorized the LRA to improve the law's application by identifying legal loopholes. As the legislation applies to all employment sectors except the security forces, it has become the main avenue for introducing IR changes. Thus Maldivian employment law exemplifies "changes which reinforce or establish protections for workers by stipulating these in legislation" (Cook, 1998:317)

Constitutional changes - solidifying the legal basis of employment rights The Maldives ushered in a new liberal Constitution ('fehi qaanoon asaasee' - the Green Constitution) on 7 August2008 when Parliament amended the 1997 Constitution ('noo qaanoonu assaasee' - the Blue Constitution ${ }^{1}$ ). The new Constitution ensured the separation of the executive, legislative, and judicial branches of the state and established new independent institutions and laws. It also extended some existing rights, reflecting the trend towards democratization, and strengthened independent bodies such as the HRCM and the CSC (FIDH, 2012). The 2008 Constitution granted a range of employment rights including the right to work, to organize trade unions, to strike, and the right of pension, and prohibited forced labour and all forms of unfair discrimination. As an HR manager of a resort noted: Constitutional rights have changed our way of life (RM17). Following the enactment of the new Constitution, the Parliament passed the Pension Act, which required all public and private employers and employees to participate in the

\footnotetext{
${ }^{1}$ The names of the constitutions were informally referred to by the colour of their covers, hence the 'Blue Constitution' and the 'Green Constitution'.
} 
Maldives Retirement Pension Scheme with a minimum monthly contribution of $7 \%$ of the pensionable wage. These constitutional rights prompted further positive developments in Maldivian IR context. Accordingly they support Fry's (2008) argument, based on his observations of Laos, that constitutional reforms strengthen labour rights.

Employee associations - from independent movements to quasi political parties Under the Association Act clubs and associations in the Maldives must be registered with the Registrar of Associations at the Ministry of Home Affairs. More than 700 associations and NGOs were registered between 2003 and 2008 (Raajje Foundation, 2009). However, before 2005, the government did not allow opposition associations to register (Shafeeg, 2011). Until 2005, when the Teachers Association of Maldives (TAM) and the Maldivian Medical Association (MMA) were allowed to register, the Law Society of Maldives was the only employee association formally in existence. The TAM and the MMA represented the interests of many government employees and, once they were registered, they energetically lobbied for salary increases for their employees until the Maldives Civil Servants Association (MCSA) was formed in 2009 following the establishment of an independent civil service.

The Tourism Employee Association of the Maldives (TEAM) is the most active employee association. It was formed in 2008 by resort workers seeking protection of their employment rights because they had been excluded from Chapter 4 of the Employment Act when it was initially enacted. Najeeb (2014) attributes this exclusion to the fact that many members of parliament were also resort owners. A TEAM executive recalled the association's beginnings as follows:

We collected 10,000 signatures from resort workers and submitted a petition to both the government and the parliament giving them an ultimatum to amend the law. We told them if they do not meet our demands, we would bring the industry to a standstill. (TM29)

Since its formation, the TEAM has continued to build its membership and act for workers in workplaces and the courts. Minivan News (2010) quoted TEAM's president:

We have 100 cases ongoing in courts ranging from the labour tribunal to the Supreme Court. I am spending $\$ 2000$ a month on the TEAM and working 20 hours a day, because resort workers are not paid enough to save up for things like lawyers.

Despite their achievements and their potential to emerge as unions, employee associations risk becoming trapped in party politics. While acknowledging the importance of political independence, employee associations also believe political affiliation is necessary to provide a voice for employees. As a TEAM executive noted:

Resorts are conforming to the Employment Act not because they really want to, but because they fear that our man [the president of TEAM - an MP] in the parliament might play the name and shame game if they don't follow the law. (TM30)

The interactions among the TEAM, the government and members of parliament reflect the choices of actors who 'seek to bend structures to suit specific needs' (Wilkinson and Wood, 2012:378). As Bhattacherjee and Ackers (2010) observe about India, one reason politicians link themselves with employee associations is that they can access large numbers of supporters who 
need skilled representation of their interests. The establishment of the TEAM also exemplifies how the political environment interacts with institutional arrangements such as the constitution and ensuing employment legislation to facilitate the rise of labour movements (Tilly, 1995). It also shows how new IR actors emerge in the absence of traditional actors such as trade unions (Michelson et al., 2009).

Employer associations-continuing to serve the elite In the 1980s when the Maldives Association for the Tourism Industry (MATI) was established, it was the only official employer association. Formed by close associates of the regime who controlled tourism, the MATI helped shape government policy on tourism. Later, during the democratization process, other employer associations such the Maldives Association for the Construction Industry (MACI) emerged. Consistent with Cooke's (2011) findings for PRC, employer associations in the Maldives put pressure on the government if legislation promised to have a negative impact on their businesses. For example, they successfully lobbied to prevent expatriate employees from enrolling in employee retirement schemes and for more favourable goods and services tax legislation. However employer associations do not engage in collective bargaining and most still do not have a significant role in developing policies for their member organisations.

Economic and labour market policy change - towards 'Aneh Dhivehi Raaje' (A different Maldives) A new MDP-led government came to power in the multi-party elections in November 2008, ending Maumoon Abdul Qayyoom's 30-year dictatorship. The MDP had campaigned with an ambitious manifesto: 'Aneh Dhivehi Raaje' (A different Maldives). The MDP's first task in government was to stabilise the economy by increasing taxes and cutting the public service. Since then it has generally pursued a centre-right economic policy of privatization, public service cuts, and seeking foreign investment (The President's Office, 2009). This agenda has been costly for employees and has further polarized Maldivian society (Nazeer, 2010).

The Maldivian government has included a labour ministry since the 1990s. At first, its function was to issue expatriate work permits, deal with unpaid wages and foreign worker repatriation (Najeeb, 2014). Under the MDP government, responsibility for labour administration, labour inspection, formulating employment policies, and employment promotion was vested in the Ministry for Youth and Sport (MHRYS). While the LRA performs labour administration and inspection functions, the MHRYS has improved training levels through university and vocational education scholarships (Shifleen, 2011). Education and training have also been extended with the establishment of the Maldives National University and the Maldives Polytechnic. MHRYS job centres helped match employees with employers in a tight labour market (Maldives Resort Workers, 2009). The government also introduced a social welfare system to protect vulnerable workers.

The IR policy changes discussed in this section show how substantial political shifts are reflected in how the economy in general and IR systems in particular function in a particular society (Thelen, 2009). It also supports the findings of Kuruvilla and Venkataratnam (1996) that in economically successful Asian countries, industrial relations policies and institutions are closely tied to economic development strategies. In particular, adopting IR policies to enhance workplace flexibility and skills enhancement is consistent with moves towards democratization. In the Maldives, however, some progressive MDP policies in education and welfare have been accompanied by some degree of labour repression. 
International actors - keeping the government under close scrutiny Maldivian IR systems have been influenced by changes in the social and political environment and by ideas transferred across national and institutional boundaries. For instance, the ILO's technical assistance was sought to draft employment legislation. The 2008 government expedited the Maldives' admission to the ILO, which was completed in May 2009. The Parliament approved ILO core conventions and the government ratified them in January 2012 (MoFA, 2013), but they are yet to be translated into the Maldivian regulatory environment. A former director of the LRA described the ILO's engagement with the Maldives this way:

The ILO started visiting the Maldives and reviewing institutional and legal provisions and advising the government on how to accede to conventions. That helped develop the government's general awareness of their obligations in terms of establishing strong industrial relations. (GO24)

Other international actors contributed to political change in the Maldives. For instance, Amnesty International published reports on the repressive nature of the Maldivian regime. The UK-based Friends of Maldives developed the pro-democracy movement's independent media capacity and exposed human rights violations. The Commonwealth and the UN provided legal and Shariah experts to help draft the new Constitution (Shafeeg, 2011). The UK High Commissioner to the Maldives organized educational forums about democracy and held Westminster talks in Sri Lanka to expedite constitutional reforms (Maldives PartnershipForum, 2006). The UK Conservative Party provided technical support to the MDP to develop its institutional capacity.

New institutions and practices emerged from these interventions, reflecting internationally recognized structures and practices. For instance, the MDP was established on a centre-right platform and the Employment Tribunal was formed as a quasi-judicial and quasi-administrative body. A high degree of pressure is also apparent in the way some international organizations and foreign governments sought to persuade the Maldivian government to comply with international human rights and democratic standards. For instance, after the August 2004 crackdown on opposition protesters, the government declared a state of emergency. The European Union responded by demanding the Maldives government implement democratic reforms or face a variety of boycotts (Shafeeg, 2011).

The nature and causes of the 'coup d'état' Although the changes described above appear revolutionary, recent events show the difficulty of sustaining truly radical shifts and these changes have not become fully institutionalized (Rupidara \& McGraw, 2010). On 7 February 2012 after three years in power, the MDP government was ousted by what the party described as a 'coup d'état' (Robinson, 2012) executed by some mutinous law enforcement agencies and political parties. A number of factors could underlie the overthrow of the MDP government and the failure to sustain the political, institutional and IR establishment. First, although 80 percent of coups in the world between 1950 and 2008 took place in countries where autocratic regimes were replaced with more democratic ones, this was not the case in the Maldives with the February 2012 coup (Lutfi, 2015). The Maldivian coup replaced the first democratically elected government with key figures who served the previous dictatorial regime which had governed the country for the 30 years prior to 2008 . Hence, this coup was undertaken not in the best interests 
of Maldivians but to pursue the vested interests of certain elite groups. Governing Maldivians is perceived to be easy and being in the government is seen as a lucrative business (Lutfi, 2015).

Second, historical and founding conditions embedded in political institutions weakened the political and IR arrangements (Bell, 2011; Lutfi, 2015). Godard (2009) argues that historical conditions and traditions become embedded in institutional norms that shape national institutional environments and trajectories. In the case of the Maldives, traditionally there had been competition between various political elites for political and vested interests. This behaviour had been embedded in the political culture of the Maldives for over 800 years. With the help of a group of political players several governments have been overthrown using havaru - a militant group of people from six main regions of the capital (Lutfi, 2015; Rasheed, 2014).

Third, despite the MDP government's best efforts to change the mechanisms of government, traditionally weak informal rules, institutions and undemocratic practices created and shaped by previous monarchical rule were transmitted over time to become embedded in the political system. This reduced the MDP government's capacity to manage socio-political and economic activities in the most democratic manner (Rasheed, 2014). The weak political system did not support efficient interactions between the government and society. There was an apparent lack of adaptive efficiency in maintaining democracy. For instance, sometimes the government failed to govern socio-political activities according to legislative and constitutional provisions (Rasheed, 2014).

Fourth, when the MDP government assumed office the local and global economies were in bad shape. Consequently it took austerity measures which did not go down well with the public. Moreover, the government introduced privatization through a private-public-partnership program (PPPP), and introduced a progressive tax system and a welfare system which hurt the ego of business elites who mobilized their resources against the MDP government (Lutfi, 2015).

Fifth, the 2008 elections only changed the executive of the state. All other machineries of the state, including the newly formed judiciary, legislature, security forces and independent institutions remained under the control of the former dictator. Consequently, most of the state machinery worked against the government. As President Nasheed stated: "it is easy to change a dictatorship but it is hard to get rid of the reminiscence of dictatorship" (Nasheed, 2013).

Finally, the pace of change was so fast it could not allow for careful planning of the execution of the projects and programs. On the one hand, the fast pace of change appears positive as the delivery of pledges started to emerge; on the other hand, the fast pace of change compromised some democratic values and principles such as rigorous public consultation, transparency, and following due process (Lutfi, 2015).

According to the historical institutional perspective, certain actors may become more powerful than others at specific times, leading to a systemic crisis (Wood et al., 2014). In the case of the Maldives, when the MDP was in power, various opposition forces at play were more powerful than the government. The media was largely controlled by these forces and religious groups used nationalistic and religious rhetoric against the government. These forces played a critical role in bringing about the February 2012 coup. Some civil society organisations and employee associations which strove to bring about democracy along with the MDP withdrew their support and joined the opposition forces as their interests were not being served by the government's 
policies. Although the MDP government tried to compromise with the opposition forces that dominated the political and social arena to make compromises, its attempts were unsuccessful as opposition forces were committed to overthrowing the government (Streek, 2012).

Beyond the 'coup d'état'- reversal of democracy and IR gains Wood and Lane (2012) argue that if the change process is only partially destructive, there is a possibility that past institutional arrangements will be reconstructed with result that might differ from the preceding regime. This effect is apparent in the case of the aftermath of the coup. The trend has been towards a complete reversal of political and IR gains made during the MDP government. Since the change of the government in 2012, constitutional rights have been threatened and some positive developments in civil and employment rights have been reversed (Rodgers, 2014). The right to elect a government of choice has been undermined by the alleged undue influence of the Supreme Court and security forces. One result is that the half-brother of the former dictator won the 2013 general and subsequent parliamentary elections. Restrictions in freedom of speech have led the country to fall from 52 $2^{\text {nd }}$ position in the 2010 Press Freedom Index to108 in 2014 (Reporters without Borders, 2014). As the government is in control of the legislature and judiciary, democratic institutions have become dysfunctional. The rules of the constitution lack check and balance mechanisms (Rasheed, 2014). Hence, in the absence of functioning democratic institutions, the current government is manipulating legislation and is imposing hierarchical authority over political and economic activities to achieve self-interested goals. For example, several opposition leaders were recently jailed on terrorism charges.

The reversal of democracy has been having a significant impact on IR. For example, in January 2013, the government ratified the Peaceful Assembly Act which prohibits all forms of protest or assembly in a tourist resort. Cases of dismissal of private and public sector employees for political activism have also been reported (Naaif, 2013; Zaheena, 2012). For instance, more than 10 employees of a public limited company were fired for attending 2015 May Day rally organised by opposition parties (Zaheena, 2015). Public sector employees have been forced to attend the ruling party's political functions. The independence of the Civil Service has also been threatened as employees have been dismissed as a result of undue influence from politicians. Hence, the job security of public sector employees is at all-time low.

The current government's commitment to IR developments is also in question as although the ILO core convention has been ratified, the relevant legal framework has not been established. Similarly, TEAM executives reported that despite their demands, the government is playing delaying tactics to avoid sending the ILO drafted IR bill to the government controlled parliament. Similarly, rather than adopting a holistic approach to initiate employment law reform, the government is arbitrarily amending the law to serve its political interests.

Due to the erosion of democratic rights, there has been a replication of events similar to those that took place in 2003-2012 to establish democracy. The role of local and international actors has been crucial in this endeavour. While ILO is continuing its engagement with the Maldivian government to develop IR systems, other international actors such as Amnesty International and the European Union have been putting pressure in a similar manner as they did previously to improve the human rights situation. Most friendly nations have also been engaging with the Maldivian government to make positive gains, although the government continues to influence them through geopolitical games (Wood et al., 2014). The government has also been countering these pressures by hiring international PR firms such as Omnia Strategy (Minivan News, 2015). 
Although international actors are making impactful gains in this process, local civil society seems to be lagging behind in the effort to restore democracy. Most NGOs disintegrated when the government that had backed them disintegrated and they have yet to reorganise and become active to create effective change.

\section{Discussion, implications and future research}

This paper presents an historical institutional evaluation of political and IR developments in the Maldives between 2003 and 2015. It highlights the ways in which a particular set of institutional arrangements may be destabilized and replaced by new arrangements through the process of political conflicts (Godard, 2009). The analysis reveals that economic development and increased formal employment from the early 1970 s to the early 2000 s were not linked to more progressive employment relations. However, consistent with North (1990), the prolonged stability of the previous institutional arrangements was interrupted by a major political crisis in September 2003, leading to new institutional arrangements. This supports Thelen's (1999:36) argument that "change in one institutional arena can reverberate, provoking changes in other complementary institutions". It is also consistent with research into IR developments in Latin America (Anner, 2008; Bronstein, 1995) linking IR change to democratization.

The political changes brought new political, legal and IR institutions and actors into Maldivian systems, including political parties, NGOs, independent institutions, employee associations, a new Constitution, and new employment laws and regulations. The government's labour and education and training policies improved and new IR actors such as job centres emerged. As Rupidara and McGraw (2010) observed about Indonesia, the ideas for the new institutions were in part sourced from outside-in, providing alternative logics to the existing institutional arrangements in the Maldives. As evidenced by the increased number of employee strikes, the establishment of new IR institutions also changed the balance of power in the workplace.

Democratic changes in the Maldives took place as a result of an open struggle over the very core of the institutional status quo - the system of governance. Local and international actors and the media all created awareness about rights, pressured the government to make political and IR changes, and facilitated the development of new institutions and laws, reflecting strong normative influence(Scott, 2008). New employment actors such as political parties, NGOs, employee associations, and agencies such as the HRCM represented employees in the absence of traditional employment actors such as trade unions and sometimes continued their IR role after trade unions were established.

The changes that took place between 2008 and 2012, such as freedom of expression and association, the employment rights granted by the Constitution and accompanying legislation, and the establishment of institutions such as the LRA and a quasi-administrative and quasijudicial employment tribunal, democratic reform and the 2008 Constitution suggest a complete break with the past. Nevertheless some of the democratic changes have not been fully institutionalized. In February 2012 the first democratically elected government of the Maldives was allegedly ousted by a coup. Since then, there has been a reversal of civil and political rights. It is significant that it has been so easy for the post-coup government to revert to the policies and practices of the past. The study identified a number of reasons for the ousting of the progressive 
government and the reversal of democratic and employment rights. The main reason is that the weak institutions, undemocratic rules, and monarchical practices embedded in the political system have persisted in the current political system constraining the government's capacity to act in the most democratic and efficient manner (Godard, 2012; Rasheed, 2014). In short, the pre-existing undemocratic rules in the Maldives inhibit the democratic reforms observed in Western societies (Bell, 2015).

A number of insights can be drawn from the analysis. First, the Maldivian experience highlights that institutional frameworks were built through the concerted efforts of social actors. This suggests that understanding the relationship between social actors and institutions is required to understand institutional change. Second, improvement in employment conditions in the Maldives resulted from institutional rather than economic change, suggesting that at least some political transformation is needed if employment rights are to be improved. Third, the change of the progressive government in 2012 and reversal of democracy and IR gains back to the old order of 1968 to 2008 suggest that just as in Latin America, there is no guarantee that civil, political and labour rights have been irrevocably secured (Anner, 2008; Bronstein, 1995). Future research should examine the changes in a longer time frame to determine whether they have indeed delivered a more equal power balance between labour and capital.

The critical incident approach used here has proved useful for defining a time-span of critical events and evaluating their significance. It could also help determine whether the February 2012 coup, the subsequent presidential elections, or some other event presents the kind of watershed in Maldivian politics and IR that the death of an inmate of the Maafushi island prison proved to be. Future research could also investigate which new international standards and practices sourced from the outside-in through normative means have been embedded in Maldivian institutions and systems. This will help determine whether and how political and economic logics in the Maldives have changed, and how its fledgling IR system is likely to develop.

Finally, while the present research identified specific political and economic factors influencing change in one country, the Maldives, future research should employ a comparative focus to illuminate whether similar patterns exist in other countries (Björkman et al., 2007). It is an intriguing question why it is so much easier to oust progressive governments in some countries than others, and how unions and other popular movements are prevented from limiting such change. Democratic change in the Maldives and its reversal have parallels with the events of the Arab Springs (Köhler \& Bonnerjee, 2012). Accordingly, the concepts and research approach of this paper could be helpful in analysing political and IR change in the Arab world.

\section{References}

Amnesty International (2005), Maldives: Put Human Rights at the Heart of the Political Reform Process. http://www.amnesty.org/en/library/asset/ASA29/002/2005/en/8f05716c-d519-11dd-8a23d58a49c0d652/asa290022005en.html (accessed 25 March 2010).

Anner, A. (2008), 'Meeting the Challenges of Industrial Restructuring: Labour Reform and Enforcement in Latin America', Latin American Politics and Society, 50, 2, 33-65.

Bar Human RightsCommittee (BHRC) (2012), Report on Bar Human Rights Committee Hearing Observation: The Maldives, A report on hearing in the case of former President Mohamed Nasheed, and meetings with lawyers, politicians, and journalists. 3-6 November 2012, 
UK. http://www.barhumanrights.org.uk/sites/default/files/documents/news/bhrc_trial_observation _report_-_mr_mohammed_nasheed_dec_2012_0.pdf (accessed 3 March 2013).

Bell, S. (2011), 'Do we really need a new 'constructivist institutionalism' to explain institutional change?' British Journal of Political Science, 41, 4, 883-906.

Barley, S. R. and Tolbert, P. S. (1997), 'Institutionalization and Structuration: Studying the Links between Action and Institution', Organization Studies, 18, 93-117.

Bhattacherjee, D. and Ackers, P. (2010), 'Introduction: Employment relations in India—old narratives and new perspectives', Industrial Relations Journal, 41, 2, 104-121.

Björkman, I., Fey, C.F., and Park, H.J. (2007), 'Institutional theory and MNC subsidiary HRM practices: Evidence from a three-country study', Journal of International Business Studies, 38, 3,430-446.

Boselie, P. (2009), 'A Balanced Approach to Understanding the Shaping of HRM in Organisations', Management Revue, 20, 1, 90-108.

Braam, G., Benders, J., and Heusinkveld, S. (2007), 'The balanced scorecard in the Netherlands: An analysis of its evolution using print-media indicators', Journal of Organisational Change Management, 20, 866-879.

Bronstein, A.S. (1995), 'Societal Change and Industrial Relations in Latin America: Trends and Prospects', International Labour Review, 134, 1, 163-186.

Campbell, M. (2004), Institutional Change and Globalization. Princeton, NJ: Princeton University Press.

Cook, M.L. (1998), 'Towards flexible industrial relations? Neo-liberalism, democracy, and labor reform in Latin America', Industrial Relations, 37, 3, 311-336.

Cooke, F.L. (2011), 'The role of the state and emergent actors in the development of human resource management in China', The International Journal of Human Resource Management, 22, 18, 38303848 .

Corbin, J. and Strauss, A.L. (2008), Basics of Qualitative Research: Grounded Theory Procedures and Techniques, 3rd edition, London: Sage.

Daniels, K., Johnson, G., and de Chernatory, L. (2002), 'Task and institutional influence on managers' mental models of competition', Organisation Studies, 23, 31-62.

DiMaggio, P. J. and Powell, W. W. (1991), Introduction. In: DiMaggio, P. J. and Powell, W. W. (eds.), The New Institutionalism in Organizational Analysis, Chicago: The University of Chicago Press.

. (1983), 'The Iron Cage Revisited: Institutional Isomorphism and Collective Rationality in Organisational Fields', American Sociological Review, 48, 147-160.

Department of National Planning (DNP) (2012), Household Income and Expenditure Survey Findings 2009/2010. Male': DNP.

Erickson, C.L. and Kuruvilla, S. (1998), 'Industrial Relations System Transformation', Industrial and Labour Relations Review, 52, 1, 3-21.

Flanagan, J.C. (1954), 'The critical incident technique', The Psychological Bulletin, 51, 4, 327-358.

Fry, S. (2008), 'Three Transformations of Industrial Relations in Laos', Journal of Industrial Relations, 50, 5, 779-795.

Gersick, C. (1991), 'Revolutionary Change Theories: A Multilevel Exploration of the Punctuated Equilibrium Paradigm', Academy of Management Review, 16, 1, 10-36.

Glaser, B.G. and Strauss A.L. (1967), The Discovery of Grounded Theory: Strategies for Qualitative Research. Chicago: Aldine Publishing Company.

Godard, J. (2012), 'Framing human resource management: The importance of national institutional environments to what management does (and should do)', in Handbook of Institutional Approach to International Business, G. Wood and M. Demirbag (eds). Cheltenham, Edward Elgar Publishing Limited, 115-141.

Godard, J. (2009), 'The Exceptional Decline of the American Labour Movement', International Labour Relations Review, 63, 1, 82-108.

Hall, P.A. (1993), 'Policy Paradigms, Social Learning and the State', Comparative Politics, 25, 275-296. Haveeruonline. (2013), Maldives shy of 1 million tourists in 2012, despite late flourish. 
http://www.haveeru.com.mv/news/46786 (accessed 29 January 2013).

Heery, E. and Frege, C. (2006), 'New Actors in Industrial Relations', British Journal of Industrial Relations, 44, 4, 601-604.

Human Rights Commission of Maldives (HRCM) (2009), Rapid Assessment of the Employment Situation in the Maldives. Male': Human Rights Commission of Maldives.

Hwang, Hokyu and Colyvas, Jeannette A. (2011), 'Problematizing Actors and Institutions in Institutional Work', Journal of Management Inquiry, 20, 1, 62-66.

International Center on Nonviolent Conflict (ICNC) (2012), 'The Maldives: From Dictatorship to Democracy and Back?' http://www.nonviolent-conflict.org/index.php/movements-andcampaigns/movements-and-campaignssummaries?sobi2Task=sobi2Details\&catid=3\&sobi2Id=35 (accessed 15 February 2014).

International Federation of Human Rights (FIDH). (2012), 'From sunrise to sunset: Maldives backtracking on democracy.' http://www.fidh.org/IMG/article_PDF/article_a12158.pdf (accessed 2 February 2013).

Jackson, G. and Muellenborn, T. (2012), 'Understanding the Role of Institutions in Industrial Relations: Perspectives from Classical Sociological Theory', Industrial Relations, 51, s1, 472-500.

Köhler, G. and Bonnerjee, A. (2012), 'What Does Democratic Reversal in the Maldives Mean for the Arab Uprisings?' International Development Economics Associates, March.http://www.policyinnovations.org/ideas/briefings/data/000233 (accessed 3 January 2013).

Kristensen, P.H. and Morgan, G. (2012), 'From Institutional Change to Experimentalist Institutions', Industrial Relations, 51, 1, 413-437.

Kuruvilla, S. and Erickson, C.L. (2002), 'Change and transformation in Asian industrial relations', Industrial Relations, 14, 2, 171-228.

Kuruvilla, S. and Venkataratnam, C.S. (1996), Economic development and industrial relations: the case of South and Southeast Asia, Industrial Relations Journal, 27, 1, 9-23.

Latheef, A. (2011), 'More than 44000 illegal expatriates, more than 99369 legal expatriates in MaldivesImmigration', Miadhu News. $15^{\text {th }}$ September.

Lutfi, M. (2015), Raees Nasheed ge democratic verikan furolhaali baghaavaai, Male', Novelty Press. (In press).

Maldives Partnership Forum (2006), The Political Reform Agenda: A mid-term progress report. UNDPGoM. http://www.maldivespartnershipforum.gov.mv/doc/Political\%20paper.pdf (accessed 25 March 2010).

Maldives Resort Workers (2009), Creating the unemployment register. 23 July 2009. http://maldivesresortworkers.wordpress.com/tag/job-center/ (accessed 30 July 2011).

March, J.G. and Olsen, J.P. (1984), 'The New Institutionalism: Organizational Factors in Political Life', The American Political Science Review, 78, 734-749.

Michelson, G., Jamieson, S., and Burgess, J. (2009), 'Filling the Void: Emerging Actors in Australian Industrial Relations', Journal of Economic and Social Policy, 13, 1, 1-17.

Ministry of Foreign Affairs (MoFA) (2010), Maldives National Report, in Accordance with Paragraph 15(a) of the Annex to Human Rights Council Resolution 5/1. Male': MoFA. .(2013), Maldives commits to core ILO legal standards. News Headlines. 7 January 2013. http://foreign.gov.mv/new/tpl/news/article/463/ (accessed 20 March 2013).

Ministry of Tourism, Arts and Culture (MTAC). (2012), Tourism Year Book 2012. Male': MTAC.

Morgan, G. and Hauptmeier, M. (2014), 'Varieties of institutional theory in comparative employment relations', in Wilkinson, A., Wood, G., and Deeg, R. (eds), Oxford Handbook of Employment Relations: Comparative Employment Systems, Oxford University Press, London.

Naaif, A. (2013), 'Vakimehakah votelaan resort ownerun gendhanee majuboorukuruvamun. Male': TEAM', Haveeruonline, 1August 2013.

Naish, A. (2011), 'Government seeks bipartisan support for economic reform package', Minivan News, 21 August 2011. . (2012), 'Human Resource Ministry owed more than MVR 350 million in unpaid work permit 
fees, student loan repayments', Minivan News, 8 November 2012.

Najeeb, A. (2013), 'The role of HR actors in designing and implementing HRM in tourist resorts in the Maldives', Employee Relations, 35, 6, 593-612.

. (2014), "Not for us, but for them': Hospitality industry stakeholder views on design and implementation challenges of Maldivian employment law', Labour and Industry, 24, 2, 124-145.

Nazeer, A. (2010), 'Some salaries restored, rest to follow in April', Minivan News, 31 January 2010.

North, D. (1990), Institutions, Institutional Change and Economic Performance. Cambridge: CUP.

Oliver, C. (1991), 'Strategic Responses to Institutional Processes', Academy of Management

Review, 16,145-179.

. (1992), 'The Antecedents of Deinstitutionalization', Organisation Studies, 13, 4, 563-588.

Raajje Foundation (2009), NGO Capacity and Needs Assessment, Male'.

http://www.undp.org/content/dam/maldives/docs/Democratic\%20Governance/NGO\%20Capacity $\% 20 \& \% 20$ Needs\%20Assessment\%20-\%20Raajje\%20Foundation.pdf (accessed 3 April 2014).

Rasheed, A. (2014), 'Historical institutionalism in the Maldives: A case of governance failure', The Maldives National Journal of Research, 2, 1, 7-28.

Reay, T., Golden-Biddle, K., and Germann, K. (2006), 'Legitimizing a new role: Small wins and microprocesses of change', Academy of Management Journal, 49, 977-998.

Reporters without Borders (2014), Press Freedom Index 2014. http://en.rsf.org (accessed 8 November 2014).

Robinson, J.J. (2010), 'Disruptive Strikes Discredits Tourism says MATATO, Mistreating Workers Does Same, Says TEAM', Minivan News, 25 August.

. (2012). 'President Waheed appoints housing, environment ministers', Minivan News, 19

February.

Rogers, B. (2014), 'The coalition must defend democracy in the Maldives', Conservative Home, http://www.conservativehome.com/platform/2014/09/benedict-rogers-the-coalition-mustdefend-democracy-in-the-maldives.html (accessed 27 September 2014).

Rupidara, N. and McGraw, P. (2010), 'Institutional Change, Continuity and Decoupling in the Indonesian Industrial Relations System', Journal of Industrial Relations, 52, 5, 613-630.

Scott, W.R. (1995), Institutions and Organizations. Thousand Oaks, CA: Sage. . (2008), Institutions and Organizations: Ideas and Interests. Thousand Oaks, CA: Sage.

Shafeeg, M.A. (2011), Dhivehi Raajje Democracy ah Kuri Dhathuru. Male': Novelty Printers and Publishers Pty Ltd.

Shaheed, A. and Upton, J. (2008), Maldives: Reform Deferred? Challenges and Lost Opportunities For Democratic Transition. Paper presented at the 9th Annual Conference of Centre for the Study of Islam and Democracy, Washington DC, 14 May.

Shifleen, A. (2011), ‘7000 Applied for Special Skills Program', Haveeruonline, 2 November 2011. http://www.haveeru.com.mv/unemployment/38548 (accessed 31 October 2014).

The President's Office (2007), Maldives: Towards a New

Dawn. http://www.presidencymaldives.gov.mv/publications/Maldives_Towards_a_New_Dawn.pdf (accessed 25 March 2010).

. (2009), Aneh Dhivehi Raajje: The Strategic Action Plan - National Framework for Development 2009-2013. http://presidencymaldives.gov.mv/4/media/downloads/AP-EN.pdf(accessed 25 March 2010).

Thelen, K. (1999), 'Historical Institutionalism in Comparative Politics', Annual Review of Political Science, 2, 369-404.

. (2009), 'Institutional Change in Advanced Political Economies', British Journal of Industrial Relations, 47, 3, 471-498.

Thornton, P.H. and Ocasio, W. (1999), 'Institutional Logics and the Historical Contingency of Power in Organizations: Executive Succession in the Higher Education Publishing Industry, 19581990', American Journal of Sociology, 105, 3, 801-843. 
Tilly, C. (1995), 'Globalization Threatens Labour Rights', International Labour and Working-Class History, 47, 1-23.

US Department of State (2009), Background Note: Maldives. http://www.state.gov/r/pa/ei/bgn/5476.htm (accessed 25 March 2010).

Wilkinson, A. and Wood, G. (2012), 'Institution and Employment Relations: The State of the Art', Industrial Relations, 51, 1, 373-388.

Wood, G. and Lane, C. (2012), 'Institutions, change and diversity', Capitalist diversity and diversity within capitalism, Routledge, Oxon.

Wood, G., Dibben, P., and Ogden, S. (2014), 'Comparative capitalism without capitalism, and production without workers: The limits and possibilities of contemporary institutional analysis,' International Journal of Management Reviews, 16, 384-396.

Zaheena, R. (2012), 'Port workers union accuses MPL of employee 'rights violations' for political Activism', Minivan News, 19 July. 